\title{
Pengembangan Massive Open Online Courses (MOOCs) pada Materi Pengelasan
}

\author{
Agus Suyetno*1, Solichin $^{2}$, Wahono ${ }^{3}$ \\ ${ }^{1,2,3}$ Program Studi S1 Pendidikan Teknik Mesin Jurusan Teknik Mesin \\ ${ }^{1,2,3}$ Fakultas Teknik Universitas Negeri Malang \\ 1,2,3 Jalan Semarang No. 5, Malang 65145 \\ e-mail: *1.
}

\begin{abstract}
Abstrak: Perkembangan dunia pendidikan saat ini tidak lepas dari perkembangan ilmu pengetahuan dan teknologi. Dunia pendidikan dituntut agar selalu bergerak seiring perkembangan teknologi global. Moodle merupakan salah satu jenis LMS (Learning Management System) yang memungkinkan komunikasi dua arah antara pendidik dan peserta didik. Matakuliah yang akan diimplementasikan dalam pengembangan inovasi sistem pembelajaran adalah matakuliah Pengelasan. Model yang digunakan dalam pengembangan MOOC pada matakuliah Pengelasan adalah model ADDIE. Tahapan dalam pengembangan model ADDIE yaitu (1) Analisis, (2) Desain/perencanaan, (3) Pengembangan, (4) Implementasi eksekusi, dan (5) Evaluasi/umpan balik. Model pengembangan ADDIE disusun secara terprogram dengan urutan-urutan kegiatan yang sistematis dalam upaya pemecahan masalah belajar yang berkaitan dengan media pembelajaran yang sesuai dengan kebutuhan dan karakteristik peserta didik. MOOC Pengelasan merupakan pengembangan dari Moodle yang disediakan oleh hosting UM, sehingga MOOC pengelasan diinstall pada domain http://mooc.um.ac.id/. MOOC Pengelasan memuat beberapa fitur dan dapat diakses oleh peserta didik, pendidik dan masyarakat umum. Fitur yang dapat diakses antara lain: (1) Rekaman aktivitas; (2) Daftar kompetensi; (3) Materi terdiri dari berbagai jenis media; (4) Forum diskusi; (5) Evaluasi dan analisis. MOOC Pengelasan yang dikembangkan terbukti dapat menunjang kegiatan praktikum, hal tersebut dapat dilihat dari angket yang disebar kepada mahasiswa. Berdasarkan angket yang disebar didapatkan hasil bahwa MOOC yang dikembangkan memiliki tingkat kelayakan yang tinggi dengan persentase $83,22 \%$. Dengan tingkat kelayakan tersebut, maka MOOC Pengelasan yang dikembangkan dianggap layak untuk digunakan dalam praktikum Pengelasan dan memiliki tingkat kelayakan yang tinggi. Berdasarkan angket yang disebar didapatkan hasil bahwa MOOC yang dikembangkan memiliki kemudahan penggunaan yang tinggi dengan persentase $84,40 \%$. Dengan tingkat kemudahan tersebut, maka MOOC Pengelasan yang dikembangkan dianggap layak untuk digunakan dalam penunjang praktikum dan mudah untuk digunakan.
\end{abstract}

Kata kunci: Moodle, MOOC, Pengelasan, Media Pembelajaran.

\begin{abstract}
The development of education today cannot be separated from the development of science and technology. The education world is demanded to always move along with the development of global technology. Moodle is a type of LMS (Learning Management System) that allows two-way communication between educators and students. The course that will be implemented in the development of learning system innovations is the Welding course. The model used in the development of MOOC in Welding subjects is the ADDIE model. The stages in developing the ADDIE model are (1) Analysis, (2) Design, (3) Development, (4) Implementation, and (5) Evaluation. The ADDIE development model is programmed in a systematic sequence of activities in an effort to solve learning problems related to learning media that are appropriate to the needs and characteristics of students. MOOC Welding is a development of Moodle provided by UM hosting, so MOOC welding is installed on the domain http://mooc.um.ac.id/. MOOC Welding contains several features and can be accessed by students, educators and the general public. Features that can be accessed include: (1) Records of activities; (2) List of competencies; (3) Material consists of various types of media; (4) Discussion forums; (5) Evaluation and analysis. MOOC Welding that was developed proved to be able to support practical activities, it can be seen from the questionnaire distributed to students. Based on the distributed questionnaire, it was found that the MOOC developed had a high level of eligibility with a percentage of $83.22 \%$. With this level of eligibility, the Welding MOOC developed is considered suitable for use in welding practicums and has a high level of eligibility. Based on the distributed questionnaire, it was found that the MOOC developed had a high ease of use with a percentage of $84.40 \%$. With this level of convenience, the Welding MOOC developed is considered suitable for use in supporting practicum and is easy to use.
\end{abstract}

Keywords: Moodle, MOOC, Welding, Learning Media. 
Proses kegiatan belajar mengajar menjadi salah satu sorotan utama dalam peningkatan mutu pendidikan. Kegiatan pembelajaran yang terdiri atas teori dan praktek, menjadi sebuah kendala saat KBM tersebut kurang efektif dan efisien. Komunikasi dua arah antara peserta didik dan pendidik mutlak diperlukan agar materi yang disampaikan benar-benar dapat dipahami oleh peserta didik. Selama ini banyak terjadi pembelajaran satu arah dari pendidik ke peserta didik, tanpa adanya respon balik dari peserta didik. Sehingga menyebabkan KBM cenderung pasif dan monoton, sehingga berakibat pada penurunan minat peserta didik dalam belajar di kelas. Hal ini juga berpengaruh pada tingkat kompetensi peserta didik saat praktek, karena teori yang disampaikan oleh guru belum dipahami secara sempurna oleh peserta didik, sehingga pelaksanaan praktek menjadi tidak optimal.

Perkembangan dunia pendidikan saat ini tidak lepas dari perkembangan ilmu pengetahuan dan teknologi. Dunia pendidikan dituntut agar selalu bergerak seiring perkembangan teknologi global. Pendidikan merupakan modal pokok dalam membangun generasi muda yang siap dalam menghadapi dunia kerja, terlebih pada era revolusi industri 4. Sistem pembelajaran di perguruan tinggi menjadi perlu dikembangkan untuk menjawab tantangan revolusi industri tersebut. Pembelajaran yang inovatif dapat dijadikan salah satu solusi untuk membuat kegiatan belajar mengajar lebih aktif karena tidak adanya batasan (borderless) sehingga kendala-kendala yang selama ini muncul dapat diatasi. Salah satu platform yang dapat digunakan sebagai pendukung inovasi sistem pembelajaran adalah Moodle. Moodle merupakan salah satu jenis LMS (Learning Management System) yang memungkinkan komunikasi dua arah antara pendidik dan peserta didik, memiliki history aktivitas dan fleksibilitas dalam penggunaan sehingga dapat memberi kemudahan bagi peserta didik dan pendidik dalam mengelola jadwal dan kegiatan pembelajaran.

Matakuliah yang akan diimplementasikan dalam pengembangan inovasi sistem pembelajaran adalah matakuliah Pengelasan. Alasan pemilihan matakuliah tersebut dikarenakan pada kegiatan pembelajaran praktik tersebut dituntut pemahaman tentang dasar teori yang kuat, tanpa pemahaman dasar teori maka yang akan dilakukan selama praktikum hanya trial \& error. Kondisi ideal yang diharapkan adalah mahasiswa memahami terlebih dahulu dasar-dasar dan konsep dalam melakukan pengelasan sebelum akhirnya melaksanakan praktikum. Alasan lain dalam pemilihan matakuliah Pengelasan karena dasar praktikum tersebut akan lebih berkembang jika didukung oleh berbagai sumber yang luas seperti foto, link artikel, dan video demonstrasi karena mengingat sifat Moodle yang borderless dan unlimited.

Desain sistem pembelajaran pengelasan secara online akan dibuat berbentuk MOOCs agar konten dan kegiatan pembelajaran pengelasan tersebut dapat bebas diakses oleh masyarakat luas, tidak hanya terbatas pada mahasiswa karena mengingat kegiatan pengelasan merupakan salah satu ketrampilan wajib dalam kegiatan manufaktur yang sangat umum dijumpai dalam kehidupan masyarakat. Dengan pengembangan MOOCs pada matakuliah Pengelasan, diharapkan dapat memberi kontribusi yang besar dalam kegiatan pembelajaran dan menjadi sumber pengetahuan bagi masyarakat umum.

\section{Rancangan Pengembangan}

\section{METODE}

Pengembangan inovasi pembelajaran yang dilakukan termasuk dalam lingkup kegiatan penelitian dan pengembangan atau research and development (R \& D). Produk yang dihasilkan adalah media pembelajaran berupa Portal E-learning matakuliah Pengelasan berbasis Moodle. Dalam pengembangan E-learning berbasis Moodle pada matakuliah Pengelasan ini menggunakan model ADDIE. Model ADDIE tersebut dipilih karena prosedur pengembangannya tersusun secara terperinci, sesuai untuk mengembangkan media pembelajaran instruksional, serta memiliki tujuan khusus yang ingin dicapai oleh media yang dikembangkan. Kelebihan lain dari model ADDIE adalah langkah pengembangan yang sederhana dan terdapat uji coba sehingga hasil pengembangan media dapat diandalkan. Model ADDIE sendiri telah berkembang menjadi berbagai jenis model pengembangan lain seperti model Dick dan Carey, model ICARE, model ASSURE dan model-model yang lain (Chen, 2011:81).

Tahapan dalam pengembangan model ADDIE yaitu (1) Analisis (Analysis), (2) Desain/perencanaan (Design), (3) Pengembangan (Development), (4) Implementasi eksekusi (Implementation), dan (5) Evaluasi/umpan balik (Evaluation). Model pengembangan ADDIE disusun secara sistematis dalam upaya pemecahan masalah belajar yang berkaitan dengan media pembelajaran yang sesuai dengan kebutuhan dan karakteristik peserta didik. 


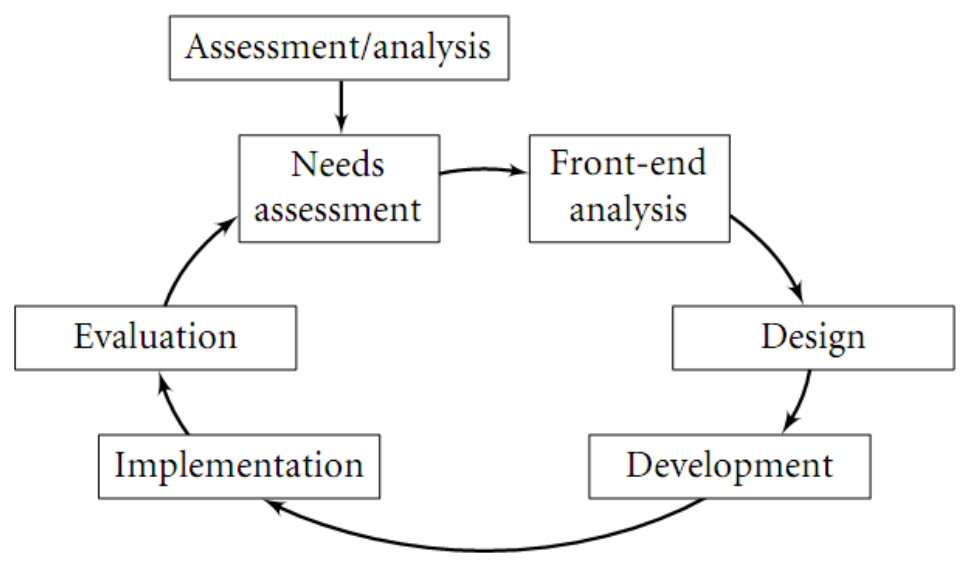

Gambar 1. Model Pengembangan ADDIE

(Sumber: Lee \& Owens, 2004:3)

\section{Prosedur Pengembangan}

Prosedur penelitian R\&D yang akan dilakukan berdasarkan model ADDIE yang dikembangkan oleh Lee dan Owens. Tahapan yang akan dilakukan antara lain: (1) tahap analisis (analysis) yang meliputi tahap analisis kebutuhan (need assessment) dan analisis hasil akhir (front-end analysis), (2) tahap desain (design), (3) tahap pengembangan (development), dan (4) tahap implementasi (implementation) (Lee \& Owens, 2004:3). Tahap kelima yaitu tahap evaluasi (evaluation) tidak dilakukan karena penelitian hanya sampai pada melihat tingkat kelayakan dari media yang dikembangkan.

\section{Tahap Analisis}

Tahap analisis merupakan awal dari proses pengembangan media pembelajaran. Dari berbagai model pengembangan yang ada, tahap analisis selalu dilakukan diawal karena akan menjadi dasar pengambangan media pembelajaran. Dengan melakukan analisis, maka akan diketahui permasalahan yang muncul dan kebutuhan apa saja yang diperlukan untuk mengatasi masalah yang muncul.

Dalam tahap analisis model ADDIE menurut Lee dan Owens, proses analisis memisahkan tahap analisis desain pembelajaran menjadi dua bagian yaitu analisis kebutuhan dan analisis hasil akhir. Analisis kebutuhan berfokus pada permasalahan yang muncul antara keadaan saat ini dengan keadaan yang diinginkan. Analisis hasil akhir berfokus pada solusi yang direkomendasikan untuk menutup permasalahan yang muncul.

\section{Tahap Desain}

Tahap desain adalah tahap perencanaan proyek media pembelajaran yang akan dikembangkan. Tujuan dari fase desain adalah untuk memverifikasi hasil yang diinginkan dan metode pengujian yang tepat (Branch, 2009:59). Perencanaan adalah faktor yang paling penting dalam keberhasilan pengembangan media pembelajaran.

Hasil dari tahap desain adalah jadwal kegiatan pengembangan media, rencana pengembangan media, garis besar pembelajaran secara terperinci, desain tampilan, rancangan konten teknis dalam media, dan metode pengujian media yang akan digunakan.

\section{Tahap Pengembangan}

Tujuan dari tahap pengembangan adalah menghasilkan media pembelajaran yang telah didesain pada tahap sebelumnya. Hasil dari tahap ini adalah MOOCs pada Matakuliah Pengelasan untuk memfasilitasi konstruksi pengetahuan dan keterampilan, dan ringkasan revisi yang dilakukan selama tahap pengembangan.

Revisi selama tahap pengembangan akan diperoleh dari validasi ahli dan validasi pengguna. Validasi merupakan upaya untuk menghasilkan media dengan tingkat validitas tinggi dan dilakukan melalui uji validitas oleh ahli dan pengguna (Akbar, 2013:37).

\section{Tahap Implementasi}

Tujuan dari tahap implementasi adalah mempersiapkan lingkungan belajar dan melakukan evaluasi formatif. Evaluasi formatif adalah proses pengumpulan data yang dapat digunakan untuk merevisi media sebelum tahap evaluasi (Branch, 
2009:83). Ada dua fase khas evaluasi formatif yang dilaksanakan yaitu: (1) uji kelompok kecil, dan (2) uji coba lapangan (Branch, 2009:123).

\section{Uji Coba Produk}

Uji coba produk dilakukan untuk mengumpulkan data yang digunakan untuk mengetahui tingkat kelayakan, efisiensi, dan daya tarik dari MOOC yang telah melalui tahapan validasi, jika masih terdapat kekurangan maka akan dilaksanakan revisi produk. Uji coba produk dalam model pengembangan ADDIE terdapat pada tahap pengembangan, implementasi dan tahap evaluasi. Pada tahap pengembangan, akan dilakukan validasi ahli media dan validasi pengguna. Padat tahap implementasi, akan dilakukan evaluasi formatif uji kelompok kecil, dan uji coba lapangan). Uji coba pada tahap implementasi difokuskan untuk merevisi dan menyempurnakan media pembelajaran yang dikembangkan.

\section{Desain Uji Coba}

Desain uji coba MOOC yang telah dibuat melewati 2 tahapan, yakni uji validasi dan evaluasi formatif. Tahap evaluasi sumatif tidak dilaksanakan karena keterbatasan yang ada sehingga dapat dikembangkan pada penelitian selanjutnya. Uji validasi terdiri dari validasi ahli media dan pengguna. Evaluasi formatif terdiri dari evaluasi satu-satu, uji kelompok kecil dan uji coba lapangan.

Validitas merupakan derajat ketepatan antara data yang terjadi pada objek penelitian dengan data yang dapat dilaporkan oleh peneliti (Sugiyono, 2011:267). Uji validitas adalah suatu langkah pengujian yang dilakukan terhadap isi (content) dengan tujuan untuk mengukur ketepatan instrumen yang digunakan dalam suatu penelitian. Uji validitas media pembelajaran berupa modul dapat dilakukan oleh ahli dan pengguna (Akbar, 2013:37). Validasi ahli adalah validasi konten media yang dilakukan oleh seorang atau beberapa ahli media pembelajaran menggunakan instrumen validasi (Akbar, 2013:37). Validasi ahli dimaksudkan untuk menilai tingkat validitas MOOC Pengelasan dan memberi masukan terkait penulisan, materi, kedalaman materi, penyajian, dan indikator-indikator lainnya. Validitas pengguna adalah validitas validasi konten media yang dilakukan oleh penyusu ataupun guru/pengguna (Akbar, 2013:37). Validasi pengguna dimaksudkan untuk mengetahui tingkat keterterapan materi pada MOOC dalam pembelajaran di kelas. Validasi pengguna juga digunakan untuk mengetahui kehebatan atau kekurangan dari sisi relevansi, akurasi, keterbacaan, dan kesesuaian pembelajaran yang berpusat pada siswa (Akbar, 2013:38).

Evaluasi formatif adalah proses pengumpulan data yang dapat digunakan untuk merevisi media sebelum tahap evaluasi sumatif (Branch, 2009:83). Sedangkan menurut Suparman (2012:302) evaluasi formatif adalah suatu proses dalam menggunakan informasi untuk dijadikan dasar pengambilan keputusan dalam rangka meningkatkan kualitas produk. Berdasarkan deskripsi tersebut, maka dapat disimpulkan bahwa evaluasi formatif adalah proses pengumpulan data yang digunakan untuk meningkatkan kualitas media pembelajaran yang dikembangkan. Ada dua evaluasi formatif yang akan dilaksanakan yaitu uji kelompok kecil, dan uji coba lapangan (Branch, 2009:123).

Uji coba kelompok kecil digunakan untuk menentukan Kelayakan MOOC yang telah direvisi berdasarkan hasil dari uji validitas. Setelah dievaluasi oleh ahli, maka media selanjutnya dievaluasi oleh sekelompok kecil peserta didik yang terdiri dari 8-20 orang (Branch, 2009:124). Suparman (2012:308) juga merekomendasikan jumlah peserta didik dalam kelompok kecil dibatasi sebanyak 8-20 orang.

Uji coba lapangan adalah langkah yang ada dalam tahap evaluasi formatif. Menurut Suparman (2012:309) uji coba lapangan dilaksanakan dengan maksud untuk mengidentifikasi kekurangan media yang dikembangkan bila digunakan dalam kondisi yang mirip dengan kondisi pada saat media tersebut digunakan dalam pembelajaran dalam kelas yang sebenarnya.

Pelaksanaan uji coba lapangan dibuat mirip dengan kondisi pada kelas yang sebenarnya akan menghasilkan data tingkat kelayakan, efisiensi dan daya tarik dari media yang dikembangkan. Hasil uji coba lapangan tidak digunakan sebagai dasar pengambilan keputusan untuk menggunakan atau membatalkan media yang dikembangkan, melainkan hanya digunakan sebagai indikator untuk melihat tingkat kelayakan media dan usaha yang harus dilakukan untuk meningkatkan kualitas produk dari media yang dikembangkan.

Menurut Suparman (2012:310) jumlah sampel dalam uji coba lapangan berkisar 20-30 orang karena dianggap cukup dan mewakili sepanjang memiliki ciri yang sama dengan populasi sasaran.

\section{Subjek Coba}

Subjek coba terdiri dari ahli di bidang isi produk, ahli di bidang perancangan produk, dan sasaran pengguna produk (PPKI UM, 2010:47). Subjek coba yang digunakan sebagai sampel selama evaluasi formatif adalah mahasiswa S1 Pendidikan Teknik Mesin Universitas Negeri Malang yang menempuh Mata Kuliah Pengelasan selama satu semester. Pada tahap uji kelompok kecil, dibutuhkan 8-10 mahasiswa sebagai subjek coba. Pada tahap uji coba lapangan, dibutuhkan 30 mahasiswa sebagai subjek coba yang mewakili populasi sasaran. 
Tabel 1. Data Sampel Uji Coba

\begin{tabular}{lll}
\hline No & Tahap Evaluasi Formatif & Jumlah Sampel \\
\hline 1 & Uji Kelompok Kecil & $8-10$ \\
2 & Uji Coba Lapangan & $20-30$ \\
\hline
\end{tabular}

(Sumber: Branch, 2009 dan Suparman, 2012)

\section{Jenis Data}

Jenis data kuantitatif yang didapat dari penyebaran angket pada tahap uji validitas digunakan untuk mengetahui tingkat kebenaran materi, kedalaman materi, keluasan materi, kesesuaian dengan kurikulum, kesesuaian dan kelayakan media yang dikembangkan. Data yang dikumpulkan dari penyebaran angket bertujuan untuk melihat tingkat kelayakan, kemudahan penggunaan dan daya tarik terhadap produk MOOC yang dihasilkan. Sedangkan tes yang diberikan untuk mengetahui seberapa besar pengaruh MOOC dalam membantu peserta didik dalam memahami materi pengelasan.

\section{Instrumen Pengumpul Data}

Pengumpulan data digunakan untuk mengetahui tingkat kelayakan MOOC yang dikembangkan. Untuk mengumpulkan data yang bermakna, digunakan instrumen pengumpul data berupa angket. Menurut Arikunto (2006:151) angket adalah sejumlah butir pertanyaan tertulis yang digunakan untuk memperoleh informasi dari responden. Instrumen tingkat kelayakan terdiri dari tiga indikator seperti pada Tabel 2.

Tabel 2. Kisi-kisi Instrumen Persepsi Mahasiswa

\begin{tabular}{|c|c|c|}
\hline Indikator & Deskriptor & $\begin{array}{l}\text { Butir } \\
\text { Instrumen }\end{array}$ \\
\hline Keakuratan & $\begin{array}{ll}\text { - } & \text { Kemampuan sebagai alat bantu pencapaian } \\
\text { indikator/tujuan pembelajaran. } \\
\text { - } \quad \text { Kemampuan untuk dapat digunakan secara berulang-ulang. } \\
\text { - } \quad \text { Efisiensi dalam kaitannya dengan waktu. } \\
\text { - } \quad \text { Efisiensi dalam kaitannya dengan biaya. } \\
\text { - } \quad \text { MOOC yang dikembangkan mampu menumbuhkan } \\
\text { semangat belajar secara mandiri. } \\
\text { - Kemampuan MOOC menjadikan peserta aktif dalam } \\
\text { pembelajaran. }\end{array}$ & $1,2,3,4,5,6$ \\
\hline $\begin{array}{l}\text { Kemudahan } \\
\text { penggunaan }\end{array}$ & $\begin{array}{l}\text { - Kemudahan penggunaan dalam kegiatan pembelajaran. } \\
\text { - Kebahasaan (bahasa dalam media mudah dipahami). } \\
\text { Kelengkapan (media menyajikan kompetensi sesuai } \\
\text { dengan tujuan pembelajaran). } \\
\text { - Kejelasan isi materi (media mudah untuk dipahami secara } \\
\text { komprehensif). } \\
\text { Ketepatan (kesesuaian materi dalam media dengan tujuan } \\
\text { pembelajaran). }\end{array}$ & $7,8,9,10,11$ \\
\hline $\begin{array}{l}\text { Aktifitas } \\
\text { belajar }\end{array}$ & $\begin{array}{l}\text { - Kemampuan dalam memicu kreativitas. } \\
\text { - } \quad \text { Kemampuan dalam menciptakan motivasi belajar. } \\
\text { - Kemampuan dalam membantu memahami informasi. }\end{array}$ & $12,13,14$ \\
\hline
\end{tabular}

(Sumber: Akbar, 2013:122)

Angket yang digunakan adalah angket tertutup, karena pada angket telah disajikan pilihan untuk dipilih serta diberi kritik atau saran sebagai masukan untuk perbaikan media oleh validator dan responden. Angket penilaian berdasarkan skala likert 5 tingkatan penilaian seperti yang dijelaskan Sugiyono (2011:134). Skala lima tingkat tersebut kemudian diubah ke dalam suatu skor seperti pada Tabel 3 .

Tabel 3. Skala likert

\begin{tabular}{ll}
\hline Skor & Keterangan \\
\hline 1 & Skor 1, apabila responden memberikan penilaian "Sangat Kurang" \\
2 & Skor 2, apabila responden memberikan penilaian "Kurang" \\
3 & Skor 3, apabila responden memberikan penilaian "Cukup" \\
4 & Skor 4, apabila responden memberikan penilaian "Baik" \\
5 & Skor 5, apabila responden memberikan penilaian "Sangat Baik" \\
\hline
\end{tabular}

(Sumber: Sugiyono, 2011:134) 


\section{Teknik Analisis Data}

Seluruh data yang telah terkumpul, kemudian diatur secara sistematis untuk dilakukan analisis. Teknik analisis data yang digunakan untuk ahli media, ahli materi, dan mahasiswa yang diperoleh dari skor angket adalah analisis deskriptif dengan menghitung persentase jawaban yang diadaptasi dari Akbar \& Sriwiyana (2010:213).

Untuk dapat memberikan makna hasil persentase maka digunakan klasifikasi penilaian yang diadaptasi dari Akbar \& Sriwiyana (2010:212) disajikan dalam Tabel 4.

Tabel 4. Kriteria Tingkat Validitas

\begin{tabular}{ll}
\hline Tingkatan Persentase & Tingkat Validitas \\
\hline $75,01 \%-100,00 \%$ & Sangat valid (dapat/layak digunakan tanpa revisi) \\
$50,01 \%-75,00 \%$ & Cukup valid (dapat/layak digunakan dengan revisi kecil) \\
$25,01 \%-50,00 \%$ & Tidak valid (tidak dapat/layak digunakan) \\
$00,00 \%-25,00 \%$ & Tidak Valid (terlarang digunakan) \\
\hline
\end{tabular}

\section{HASIL}

Menurut Munir (2009:180), Moodle adalah salah satu aplikasi E-learning yang berbasis open source. Moodle adalah software yang dikhususkan untuk digunakan dalam kegiatan belajar berbasis internet dan website. Moodle dikembangkan oleh Martin Dogiamas dan dipertahankan sebagai paket software E-learning yang gratis (free) dan sumber program terbuka (open source). Moodle selalu melakukan pengembangan sistem dan desain user interface (up to date), sehingga penggunaan Moodle diharapkan dapat meningkatkan efisiensi dan efektivitas kinerja pengajar dan pemahaman pembelajar terhadap materi pembelajaran.

Pengembangan MOOC pengelasan berbasis Moodle diharapkan dapat membantu dalam kegiatan pembelajaran dan meningkatkan interaksi dengan sumber belajar. Adanya interaktifitas sangat diutamakan pada pengembangan produk pembelajaran E-learning berbasis Moodle ini. Hal tersebut dipicu dengan bentuk pemberian stimulus-respon yang berupa feedback, disamping itu peserta didik dapat memilih sumber belajar berupa foto, link artikel dan video baik yang sudah disediakan atau yang dapat ditemukan sendiri secara online.

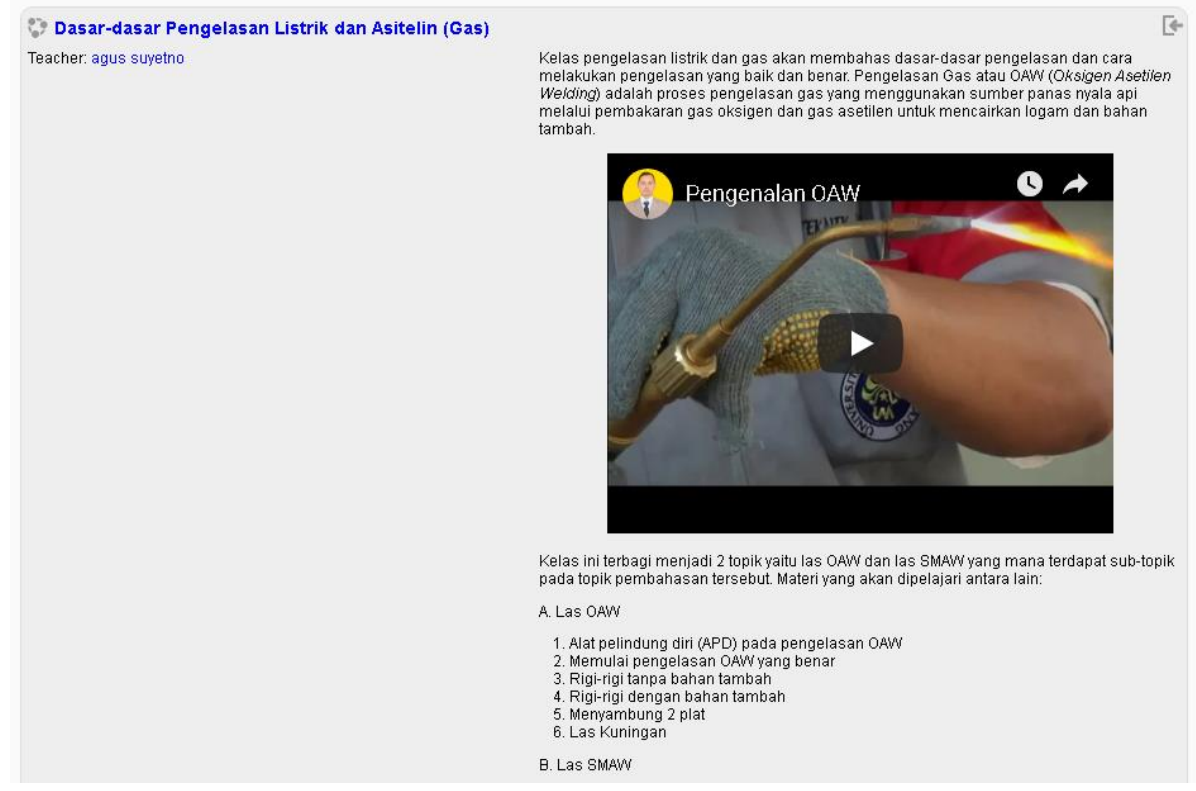

Gambar 2. Halaman awal MOOC Pengelasan

Produk yang dikembangkan dalam pengembangan ini terpusat pada pengembangan produk E-learning berbasis Moodle pada matakuliah Pengelasan yang berupa website dan dapat diakses secara online. E-learning pengelasan berbasis Moodle diharapkan dapat membantu dalam kegiatan pembelajaran dan meningkatkan interaksi dengan sumber belajar. Adanya interaktifitas sangat diutamakan pada pengembangan produk pembelajaran E-learning berbasis Moodle ini. Hal tersebut dipicu dengan bentuk pemberian stimulus-respon yang berupa feedback, disamping itu peserta didik dapat memilih sumber belajar berupa foto, link artikel dan video baik yang sudah disediakan atau yang dapat ditemukan sendiri secara online. 
MOOC yang dikembangkan merupakan pengembangan dari Moodle yang disediakan oleh hosting UM, sehingga MOOC pengelasan diinstall pada domain http://mooc.um.ac.id/. MOOC Pengelasan berbasis Moodle ini memuat beberapa fitur dan dapat diakses oleh peserta didik, pendidik dan masyarakat umum. Fitur yang dapat diakses antara lain: (1) Rekaman aktivitas; (2) Daftar kompetensi; (3) Materi terdiri dari berbagai jenis media; (4) Forum diskusi; (5) Evaluasi dan analisis.

\section{Rekaman Aktivitas Peserta}

Aktifitas yang dilakukan peserta dapat menggambarkan tingkat keaktifan dari peserta tersebut. Aktifitas peserta yang direkam didalam MOOC antara lain login, logout, pengumpulan tugas, diskusi dan komentar. Rekaman login dan logout sebagai sarana identitas masuk dan keluar kelas online dan dapat digunakan untuk menilai tingkat keaktifan peserta didik. Username dan Password diperlukan agar peserta dapat login ke MOOC. Bagi pengguna baru yang belum memiliki Username, maka harus mendaftar terlebih dahulu dengan mengklik tombol Create new account.

\section{Materi}

Materi yang disajikan berisi teks, gambar dan video khususnya tentang dasar-dasar pengelasan dan cara melakukan pengelasan berbagai posisi pengelasan yang baik dan benar.

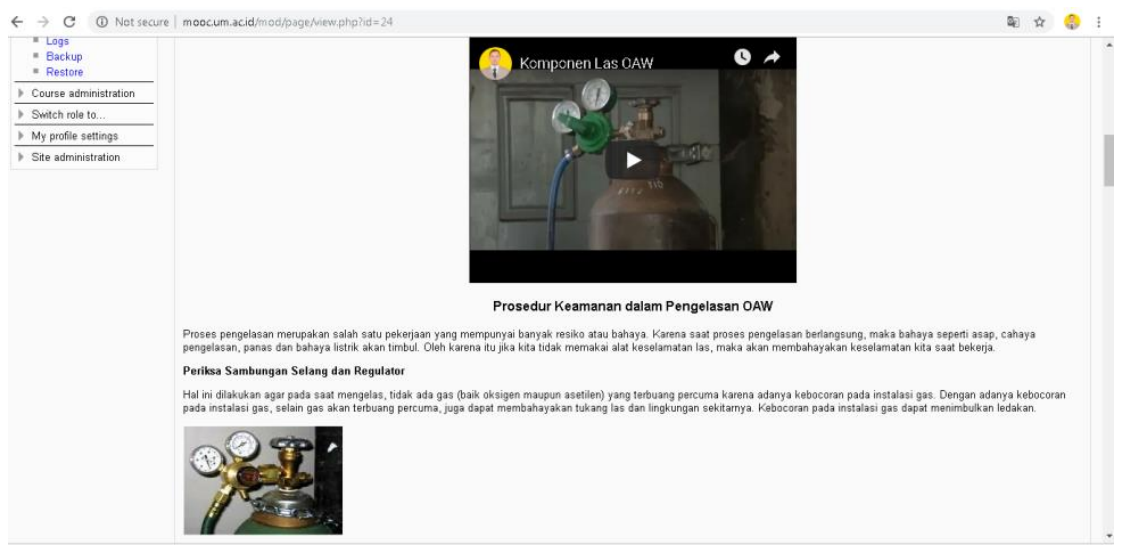

Gambar 3. Materi pengelasan terdiri dari materi teks, gambar dan video.

File pdf, word, dan ppt juga disisipkan dalam materi sehingga peserta dapat mendownload materi tersebut dengan mengakses link yang diberikan.

\section{Forum Diskusi dan Evaluasi}

Forum diskusi memungkinkan peserta didik memaparkan hasil pengelasan dan mengkoreksi pemaparan/presentasi dari peserta didik lain. Forum diskusi ditampilkan pada setiap topik pembelajaran. Forum diskusi dilakukan untuk membahas hasil praktikum. Histori diskusi dapat digunakan sebagai bagian dari penilaian keaktifan peserta dalam kelas.

Evaluasi disusun dalam bentuk soal-soal baik berupa pilihan ganda, isian, maupun uraian serta tautan foto dan video hasil kegiatan pengelasan.

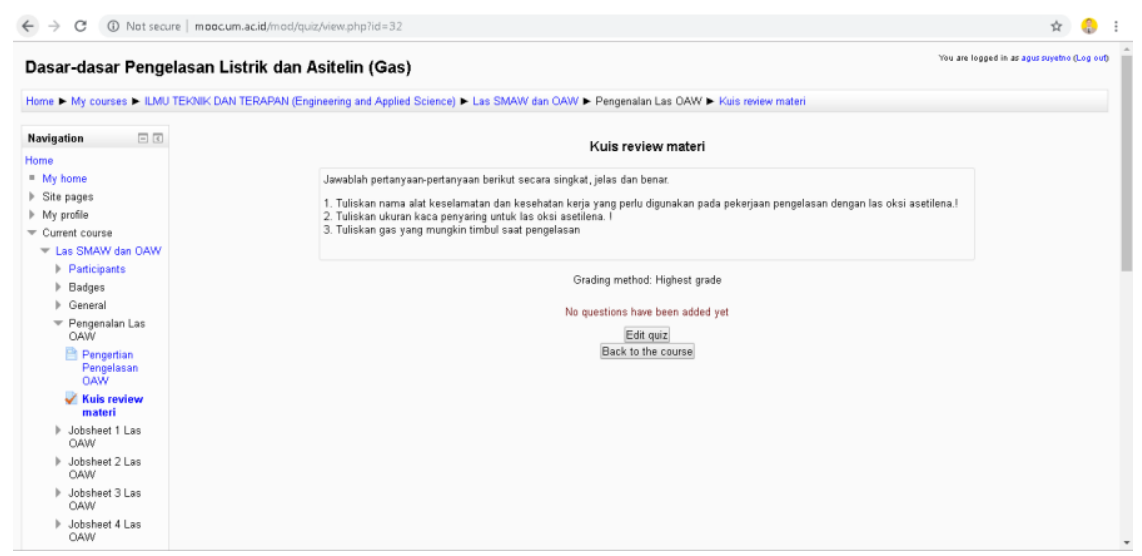

Gambar 4. Soal esai pada akhir jobsheet 
Setiap mahasiswa yang akan melaksanakan kegiatan praktikum diwajibkan minimal telah lulus dari evaluasi yang telah dilakukan setiap awal minggu. Dengan peraturan demikian, maka diharapkan kegiatan praktikum dapat dilaksanakan dengan dasar teori yang benar dan mengikuti kaidah keselamatan kerja.

\section{Hasil Uji Coba Kelompok}

\section{PEMBAHASAN}

Uji coba kelompok kecil dilakukan kepada 10 mahasiswa yang menempuh Mata Kuliah Pengelasan. Pelaksanaan uji coba dilakukan di Laboratorium Instrumentasi dan Kontrol Jurusan Teknik Mesin Universitas Negeri Malang dikarenakan pada Lab tersebut tersedia perangkat komputer dan koneksi internet yang stabil. Penyebaran angket dilakukan untuk mengetahui persepsi mahasiswa terkait MOOC Pengelasan yang dikembangkan. Angket yang disebarkan terdiri dari tiga indikator yaitu: (1) kelayakan penggunaan, (2) kemudahan penggunaan, dan (3) aktifitas belajar. Hasil dari angket yang disebar dapat dilihat pada Tabel 5.

Tabel 5. Rekapitulasi Angket Persepsi Mahasiswa

\begin{tabular}{cccccccccccccccc}
\hline \multirow{2}{*}{$\begin{array}{c}\text { Responden } \\
\text { Ke- }\end{array}$} & $\mathbf{1}$ & $\mathbf{2}$ & $\mathbf{3}$ & $\mathbf{4}$ & $\mathbf{5}$ & $\mathbf{6}$ & $\mathbf{7}$ & $\mathbf{8}$ & $\mathbf{9}$ & $\mathbf{1 0}$ & $\mathbf{1 1}$ & $\mathbf{1 2}$ & $\mathbf{1 3}$ & $\mathbf{1 4}$ & Total \\
\hline 1 & 4 & 5 & 4 & 5 & 5 & 5 & 4 & 5 & 5 & 4 & 5 & 5 & 4 & 5 & 65 \\
2 & 4 & 5 & 4 & 4 & 5 & 5 & 5 & 4 & 5 & 5 & 5 & 4 & 4 & 5 & 64 \\
3 & 5 & 4 & 5 & 5 & 4 & 4 & 5 & 4 & 4 & 4 & 4 & 4 & 5 & 5 & 62 \\
4 & 5 & 5 & 5 & 4 & 5 & 5 & 4 & 4 & 4 & 4 & 5 & 4 & 4 & 4 & 62 \\
5 & 5 & 5 & 4 & 4 & 5 & 5 & 5 & 5 & 4 & 5 & 5 & 4 & 5 & 4 & 65 \\
6 & 5 & 5 & 4 & 3 & 5 & 5 & 4 & 4 & 5 & 4 & 5 & 4 & 5 & 5 & 63 \\
7 & 5 & 5 & 4 & 3 & 5 & 5 & 4 & 3 & 5 & 3 & 4 & 5 & 5 & 5 & 61 \\
8 & 5 & 5 & 5 & 5 & 5 & 5 & 5 & 4 & 5 & 4 & 5 & 5 & 5 & 5 & 68 \\
9 & 5 & 5 & 4 & 4 & 5 & 5 & 4 & 5 & 4 & 5 & 4 & 4 & 4 & 5 & 63 \\
10 & 5 & 5 & 5 & 4 & 5 & 5 & 5 & 5 & 4 & 5 & 5 & 5 & 4 & 5 & 67 \\
\hline
\end{tabular}

Kelayakan MOOC (Butir Instrumen 1-6)

$$
\begin{aligned}
\mathrm{V} & =\frac{\sum \mathrm{TSEV}}{\sum \mathrm{S}-\max } \times 100 \% \\
& =\frac{280}{300} \times 100 \% \\
& =93,33 \%
\end{aligned}
$$

Kemudahan Penggunaan (Butir Instrumen 7-11)

$$
\begin{aligned}
\mathrm{V} & =\frac{\sum \mathrm{TSEV}}{\sum \mathrm{S}-\max } \times 100 \% \\
& =\frac{223}{250} \times 100 \% \\
& =89,00 \%
\end{aligned}
$$

Aktifitas Belajar (Butir Instrumen 12-14)

$$
\begin{aligned}
\mathrm{V} & =\frac{\sum \mathrm{TSEV}}{\sum \mathrm{S}-\max } \times 100 \% \\
& =\frac{137}{150} \times 100 \% \\
& =91,33 \%
\end{aligned}
$$

Hasil Akhir:

$$
\mathrm{V}=\frac{\sum \mathrm{TSEV}}{\sum \mathrm{S}-\max } \times 100 \%
$$




$$
\begin{aligned}
& =\frac{640}{700} \times 100 \% \\
& =91,43 \%
\end{aligned}
$$

Berdasarkan perhitungan di atas, persentase penghitungan hasil akhir pada Tabel 5 adalah 91,43\%. Mengacu pada Tabel 4 tentang kriteria tingkat validitas, maka penilaian MOOC berdasarkan butir instrumen pada angket yang dibuat termasuk dalam tingkat yang valid sehingga layak untuk digunakan.

\section{Hasil Uji Coba Lapangan}

Uji coba lapangan dilakukan kepada 30 mahasiswa yang menempuh Mata Kuliah Pengelasan. Pelaksanaan uji coba dilakukan di Laboratorium Instrumentasi dan Kontrol Jurusan Teknik Mesin Universitas Negeri Malang. Pada tahap uji coba lapangan, penyebaran angket dilakukan untuk mengetahui persepsi mahasiswa terkait MOOC. Hasil dari angket yang disebar dapat dilihat pada Tabel 6.

\begin{tabular}{|c|c|c|c|c|c|c|c|c|c|c|c|c|c|c|c|}
\hline \multirow{2}{*}{$\begin{array}{c}\text { Responden } \\
\text { Ke- }\end{array}$} & \multicolumn{14}{|c|}{ Butir Instrumen } & \multirow[t]{2}{*}{ Total } \\
\hline & 1 & 2 & 3 & 4 & 5 & 6 & 7 & 8 & 9 & 10 & 11 & 12 & 13 & 14 & \\
\hline 1 & 5 & 5 & 4 & 4 & 4 & 5 & 5 & 4 & 4 & 4 & 4 & 5 & 5 & 5 & 63 \\
\hline 2 & 4 & 4 & 5 & 5 & 4 & 4 & 3 & 3 & 4 & 4 & 4 & 4 & 4 & 4 & 56 \\
\hline 3 & 4 & 5 & 4 & 3 & 4 & 5 & 4 & 5 & 4 & 4 & 4 & 5 & 4 & 5 & 60 \\
\hline 4 & 4 & 4 & 3 & 4 & 5 & 5 & 4 & 4 & 4 & 4 & 5 & 5 & 5 & 4 & 60 \\
\hline 5 & 5 & 5 & 4 & 3 & 4 & 4 & 5 & 3 & 3 & 4 & 4 & 5 & 4 & 4 & 57 \\
\hline 6 & 5 & 5 & 4 & 5 & 5 & 3 & 4 & 5 & 5 & 5 & 4 & 4 & 3 & 4 & 61 \\
\hline 7 & 3 & 3 & 3 & 3 & 3 & 4 & 3 & 3 & 4 & 4 & 4 & 3 & 3 & 5 & 48 \\
\hline 8 & 4 & 3 & 3 & 5 & 5 & 4 & 5 & 4 & 3 & 4 & 4 & 4 & 4 & 4 & 56 \\
\hline 9 & 4 & 5 & 3 & 4 & 4 & 5 & 5 & 4 & 4 & 4 & 5 & 5 & 5 & 4 & 61 \\
\hline 10 & 5 & 5 & 5 & 4 & 5 & 3 & 4 & 5 & 5 & 4 & 4 & 3 & 3 & 3 & 58 \\
\hline 11 & 4 & 3 & 4 & 5 & 4 & 3 & 4 & 4 & 5 & 5 & 4 & 5 & 4 & 3 & 57 \\
\hline 12 & 4 & 3 & 2 & 3 & 3 & 4 & 4 & 4 & 4 & 4 & 3 & 2 & 3 & 4 & 47 \\
\hline 13 & 4 & 4 & 4 & 4 & 3 & 3 & 3 & 3 & 4 & 3 & 3 & 3 & 3 & 3 & 47 \\
\hline 14 & 5 & 4 & 4 & 3 & 4 & 4 & 4 & 3 & 4 & 5 & 3 & 4 & 2 & 3 & 52 \\
\hline 15 & 4 & 4 & 2 & 3 & 4 & 4 & 4 & 4 & 4 & 3 & 3 & 4 & 4 & 3 & 50 \\
\hline 16 & 5 & 5 & 5 & 5 & 4 & 4 & 5 & 5 & 4 & 5 & 5 & 5 & 5 & 5 & 67 \\
\hline 17 & 5 & 4 & 4 & 4 & 4 & 3 & 4 & 4 & 4 & 4 & 3 & 4 & 4 & 3 & 54 \\
\hline 18 & 4 & 3 & 4 & 4 & 4 & 3 & 4 & 3 & 4 & 4 & 4 & 3 & 4 & 3 & 51 \\
\hline 19 & 5 & 4 & 5 & 4 & 5 & 4 & 5 & 5 & 5 & 4 & 5 & 3 & 4 & 4 & 62 \\
\hline 20 & 4 & 4 & 4 & 3 & 4 & 4 & 5 & 4 & 4 & 4 & 4 & 3 & 3 & 4 & 54 \\
\hline 21 & 5 & 5 & 5 & 4 & 5 & 5 & 5 & 5 & 4 & 5 & 4 & 5 & 5 & 5 & 67 \\
\hline 22 & 5 & 5 & 4 & 3 & 5 & 4 & 5 & 5 & 5 & 4 & 5 & 5 & 5 & 5 & 65 \\
\hline 23 & 5 & 5 & 4 & 4 & 4 & 5 & 5 & 4 & 5 & 5 & 5 & 5 & 5 & 5 & 66 \\
\hline 24 & 5 & 5 & 5 & 5 & 5 & 5 & 4 & 5 & 5 & 4 & 5 & 5 & 4 & 5 & 67 \\
\hline 25 & 4 & 4 & 4 & 4 & 4 & 4 & 4 & 4 & 5 & 4 & 5 & 5 & 5 & 4 & 60 \\
\hline 26 & 4 & 4 & 3 & 4 & 3 & 4 & 5 & 5 & 4 & 4 & 4 & 5 & 5 & 5 & 59 \\
\hline 27 & 5 & 5 & 4 & 4 & 5 & 5 & 5 & 5 & 5 & 4 & 5 & 5 & 4 & 5 & 66 \\
\hline 28 & 5 & 4 & 3 & 4 & 5 & 5 & 4 & 5 & 4 & 4 & 5 & 5 & 5 & 4 & 62 \\
\hline 29 & 5 & 4 & 5 & 5 & 5 & 4 & 4 & 4 & 5 & 4 & 4 & 5 & 4 & 4 & 62 \\
\hline 30 & 5 & 4 & 3 & 4 & 5 & 5 & 4 & 5 & 4 & 4 & 5 & 5 & 5 & 4 & 62 \\
\hline
\end{tabular}

Tabel 6. Rekapitulasi Angket Persepsi Mahasiswa

Kelayakan MOOC (Butir Instrumen 1-6)

$$
\begin{aligned}
\mathrm{V} & =\frac{\sum \mathrm{TSEV}}{\sum \mathrm{S}-\max } \times 100 \% \\
& =\frac{749}{900} \times 100 \% \\
& =83,22 \%
\end{aligned}
$$

Kemudahan Penggunaan (Butir Instrumen 7-11)

$$
\mathrm{V}=\frac{\sum \mathrm{TSEV}}{\sum \mathrm{S}-\max } \times 100 \%
$$




$$
\begin{aligned}
& =\frac{633}{750} \times 100 \% \\
& =84,40 \%
\end{aligned}
$$

Aktifitas Belajar (Butir Instrumen 12-14)

$$
\begin{aligned}
\mathrm{V} & =\frac{\sum \mathrm{TSEV}}{\sum \mathrm{S}-\max } \times 100 \% \\
& =\frac{375}{450} \times 100 \% \\
& =83,33 \%
\end{aligned}
$$

Hasil Akhir:

$$
\begin{aligned}
\mathrm{V} & =\frac{\sum \mathrm{TSEV}}{\sum \mathrm{S}-\max } \times 100 \% \\
& =\frac{1757}{2100} \times 100 \% \\
& =83,673 \%
\end{aligned}
$$

Berdasarkan perhitungan di atas, persentase penghitungan hasil akhir pada Tabel 6 adalah 83,67\%. Mengacu pada Tabel 4 tentang kriteria tingkat validitas, maka penilaian MOOC berdasarkan butir instrumen pada angket yang dibuat termasuk dalam tingkat yang valid sehingga layak untuk digunakan dalam pembelajaran.

\section{Analisis Kelayakan}

SIMPULAN

MOOC Pengelasan yang dikembangkan terbukti dapat menunjang kegiatan praktikum, hal tersebut dapat dilihat dari angket yang disebar kepada mahasiswa. Berdasarkan angket yang disebar didapatkan hasil bahwa MOOC yang dikembangkan memiliki tingkat kelayakan yang tinggi dengan persentase 83,22\%. Dengan tingkat kelayakan tersebut, maka MOOC Pengelasan yang dikembangkan dianggap layak untuk digunakan dalam praktikum Pengelasan dan memiliki tingkat kelayakan yang tinggi.

Kemudahan penggunaan MOOC dapat dilihat dari tingkat keberhasilan mahasiswa dalam memahami materi dan pelaksanaan praktikum pengelasan. Rata-rata mahasiswa tidak mengalami kesulitan yang berarti dalam melakukan praktikum setelah memahami dan melihat video tutorial pada MOOC. Berdasarkan angket yang disebar didapatkan hasil bahwa MOOC yang dikembangkan memiliki kemudahan penggunaan yang tinggi dengan persentase $84,40 \%$. Dengan tingkat kemudahan tersebut, maka MOOC Pengelasan yang dikembangkan dianggap layak untuk digunakan dalam penunjang praktikum dan mudah untuk digunakan.

\section{Keunggulan MOOC Pengelasan}

MOOC Pengelasan dikembangkan dengan harapan dapat menanggulangi keterbatasan kelas tatap muka yang ada. Penerapan MOOC dalam pembelajaran terbukti dapat membantu pendidik maupun peserta didik untuk memahami materi. Keunggulan MOOC pengelasan yang didapat antara lain: (1) Pengajar mempunyai hak istimewa, yaitu dapat mengubah (memodifikasi) materi pembelajaran. Pengajar dapat mengatur kegiatan pelajaran seperti memilih bentuk atau metode pembelajaran dalam bentuk mingguan, berdasarkan topik atau bentuk diskusi; (2) Materi dan sumber belajar yang telah disusun dapat digunakan ulang pada praktikum di kelas selanjutnya, sehingga memudahkan pengajar dalam menyusun bahan ajar; (3) Pelajaran dapat dilengkapi dengan penjelasan dan dapat dipilah menjadi beberapa kategori; dan (4) Teknologi yang digunakan bersifat sederhana, sehingga mudah digunakan, relatif murah, dan efisien.

\section{SARAN}

MOOC Pengelasan yang telah dikembangkan memiliki tingkat kelayakan yang tinggi sehingga dapat digunakan oleh mahasiswa secara individu, sehingga disarankan setiap peserta didik yang menempuh Mata Kuliah Pengelasan maupun yang belajar materi pengelasan secara mandiri mengakses MOOC Pengelasan tersebut.

Kepada para mengembang berikutnya yang berminat pada bidang pembelajaran pengelasan agar melakukan penelitian dan pengembangan pada lingkup yang lebih luas, tidak terbatas pada materi yang berbasis kompetensi pada Mata Kuliah Pengelasan, namun berkembang sampai pada tingkat pengelasan lanjut. 
151 Agus Suyetno, Solichin, Wahono - Pengembangan Massive Open Online Courses (MOOCs) .....

Pengembangan MOOC Pengelasan hanya terbatas sampai tahap implementasi dan tidak sampai pada tahap evaluasi, sehingga bagi pengembang selanjutnya dapat melakukan evaluasi. Tahap evaluasi digunakan untuk melihat tingkat keefektifan dan pengaruh penggunaan MOOC Pengelasan jika digunakan pada pembelajaran yang berulang-ulang. Dengan adanya tahap evaluasi, diharapkan proses penyebaran dan penggunaan media pembelajaran dapat bermanfaat bagi kegiatan pembelajaran di kelas.

\section{DAFTAR RUJUKAN}

Akbar, S. \& Sriwiyana, H. 2010. Pengembangan Kurikulum dan Pembelajaran Ilmu Pengetahuan Sosial. Yogyakarta: Cipta Media.

Akbar, S. 2013. Instrumen Perangkat Pembelajaran. Bandung: PT Remaja Rosdakarya.

Anonim. 2010. Pedoman Penulisan Karya Ilmiah (PPKI UM). Malang: UM Press.

Arikunto, S. 2006. Prosedur Penelitian: Suatu Pendekatan Praktek. Jakarta: PT. Rineka Cipta.

Branch, R.M. 2009. Instructional Design: The ADDIE Approach. New York: Springer.

Chen, I. 2011. Instructional Design: Concepts, Methodologies, Tools, and Applications. New York: IGI Global.

Lee, William W. \& Owens, Diana L. 2004. Multimedia-Based Instructional Design, Second Edition. United States of America: John Wiley \& Sons, Inc.

Munir. 2009. Pembelajaran Jarak Jauh Berbasis Teknologi Informasi dan Komunikasi. Bandung: Alfabeta.

Sugiyono. 2011. Metode Penelitian Pendidikan, Pendekatan Kuantitatif, Kualitatif dan R\&D. Bandung: Penerbit Alfabeta.

Suparman, M.A. 2012. Desain Instruksional Modern. Jakarta: Erlangga. 